\title{
DOUKHOBORISM AND REVITALIZATION
}

\section{Norman R. Yetman \\ University of Kansas}

The past few years have witnessed a surge of interest - both theoretical and descriptive - in those elements of cultural dynamics which have been variously designated as "nativistic,"1 "revitalization," 2 or "social"3 movements. Most of the movements considered for inclusion under one of the numerous rubrics employed to classify such phenomena have been characterized by the dramatic manner in which they ostensibly deviated from the status quo. The common denominator of all such movements, however defined, is that each has sought, usually consciously, to effect a modification or reorganization of the existing social-cultural order.

The etiology of such movements have invariably been attributed to a psychological sense of alienation from the existing order. 4 This psychological stress is alleged to elicit reactions which seek to reduce the tension by a reorganization of the social order to one more psychologically compatible. The ascription of psychological stress immediately raises several salient questions which must be more adequately dealt with before a general theory of movements can be derived. First is the problem that a movement is recognized and defined as such only in retrospect; situations in which stress is present and a movement does not emerge are not considered. The relationship between a movement and alleged stress therefore becomes tautological: stress was present, so therefore a movement was generated, and the movement is cited as evidence that stress did exist. Therefore some empirical means must be achieved for testing the assumptions of "stress" and determining the necessary and sufficient conditions for the emergence of a movement.

The recent interest in such phenomena was sparked by Ralph Linton's seminal paper on "nativistic movements."5 His work inspired a number of articles which sought to further elaborate upon the taxonomic scheme which he had constructed to explain the ideology of a movement. 6 However, a more fruitful approach has sought to ilumine the common processural elements informing these movements. Interest in the processural development of specific movements, exem- 
plified by Pope's elaboration of the church-sect typology, 7 antedates the more recent attempts to derive a general theory of the dynamics of movements. Recently Wallace, 8 Parsons, 9 and King 10 have posited similar theoretical models which seek to account for a movement in terms of a series of stages or phases which characterize its "natural terms of a series of stag
history," once initiated.

Among the most colorful and enduring groups to be so considered are the Doukhobors, a Russian religious sect, some of whose members migrated to western Canada early in the twentieth century. The Doukhobors have historically conflicted with civil and religious authorities, a conflict which continues in Canada to the present and from which derives the notoriety which the sect enjoys. While a majority of its ideological adherents have adapted to the dominant culture, a "hard core" of resistance has sought to perpetuate the movement, though not without radical alterations, for over 200 years. 11

Definitive analysis of the Doukhobors is limited by the paucity of relevent historical data on their genesis and development. This is especially true of the former aspect, since fragmentary evidence limits an adequate appraisal of the initial cultural milieu from the ideology which has defined the movement emerged. Even more significantly, however, this totally precludes an evaluation of the psychological stresses and dissatisfactions felt by those who adopted the Doukhobor tenets. Any judgment of the psychological reality of the existing conditions must therefore remain problematical. Despite these and numerous other problems, analysis of this group is valuable in that it exemplifies many of the problems posed by the attempt to derive a general theory of social movements. It will be the purpose of this paper to undertake to analyze the phenomenon of Doukhoborism. It will consist of two sections: a brief historical sketch of the origins, development, and dynamics of the sect, and an analysis of the movement and several of the theoretical implications it poses.

The origins of Doukhoborism are obscure, and, although the broad context from which the movement emerged can be delineated, such analysis can be little more than suggestive. Religious dissent was not a factor unique to those who became known as Doukhobors or "spirit-wrestlers." A long tradition of dissent, revealing a great diversity of form and content, antedated their appearance. The fifteenth through the seventeenth centuries witnessed religious controversies which pervaded all of western Russia and culminated in the seventeenth century Schism which rent the Orthodox Church. The subject of this schism was, ostensibly, a number of liturgical matters which had been declared definitive by the Russian Orthodox councils but which conflicted with the academically authoritative but less nationalistic
Greek sources. These matters, which appear trivial and "utterly insignificant issues" to one historian, 12 nevertheless were the immediate conditions from which the Schism erupted and which had widespread and lasting repercussions on the outlines of Russian culture.

The schism initiated a period of turbulence which would ultimately spawn a number of Russian sects, among which were the Doukhobors. Yet the manner in which the Doukhobors emerged is problematic, for the Schism was fought within the framework of the authority of the Church. Disputants concurred in the efficacy of its rituals, but differed over the administration of them. Numerous of the other religious dissidents, however, forged radical new religious systems which rejected the basic framework of the ancient orthodoxy itself. As the seventeenth century drew to a close, revulsion at official civil and religious institutions and their officials was widespread.

Amid this antagonism religious unrest was further stirred by a reviva of earlier Russian apocalyptic and millenarian utterances and the infusion of non-Russian religious currents, particularly German Lutheran and mystical doctrines. From this ferment emerged a number of ideological currents which emphasized a more mystical, individualistic, anti-institutional, "spiritual" doctrine; in the first half of the eighteenth century self-appointed prophets claiming divine sanction and preaching a more mysitcal and anarchic Christian synthesis flourished. The Doukhobors were among the most prominent of several sects which proclaimed such radical doctrines. Precisely when those embracing these doctrines evolved the distinctive Doukhobor ideology cannot be determined. But the roots of its doctrine and the dynamics which gave impetus to its organization as a concerted movement can be attributed to this religious turbulence. The controversies of the period provided ample precedent for several of those features of Doukhoborism which later appear to be innovations; the continuities with this earlier tradition throughout the history of Doukhoborism are more real than is at first glance apparent.

Precisely when several disparate ideological elements crystallized into the coherent doctrine which historically has distinguished Doukhoborism is unknown. An anonymous foreigner, allegedly a German Quaker, is traditionally credited with having introduced them in systematic form. Though these tenets were to be spread throughout the whole of the Russian empire, they initially appeared in the provinces of Ekaterinoslav and Tambov in the Ukraine region of southwestern Russia.

By the turn of the nineteenth century Doukhobor doctrine had been welded into a coherent and distinctive form. The essentials of this formal catechism appear to have persisted virtually without modification to the present, although in reality it has been subjected to a diversity of interpretation and informal additions, which have periodi- 
cally altered the experiential significance of the creed. Although it is impossible to determine the extent to which the tenets of the Doukhobors were originally born, as Wallace maintains is generally the case, of individual hallucinatory visions, the fact remains that a new Gestalt, ideologically radically different from the then existing definitions of reality, did appear.

The most radical doctrinal departure from the orthodox tradition was the rejection of the power of all external authority - civil and religious - and the promulgation of a doctrine of extreme individualism in its stead. The authority of the established church and the efficacy of its rituals, creeds, and priesthood were denied as unnecessary. The true Church was held to be invisible and universal and effected by the infusion of the spirit of God within an individual. The established Orthodox Church was asserted to represent corrupt visages of the true faith, which was discernible only by reliance upon the "voice within." All men were equally able to discern the truth for themselves, and no individual could dictate the proper behavior or belief of another. Therefore the Doukhobors will not openly acknowledge earthly leadership.

In common with all of Russian sectarianism, Doukhoborism was intensely mystical, an attribute which, when coupled with Doukhobor anti-institutionalism, appeared conducive to a form of democratic anarchism. Indeed, Doukhobor professions of the denial of external authority were also extended to a rejection of the validity of civil statutes, ordinances, officials - in short, all earthly power except that which they chose to respect. Their repudiation of human laws was manifested particularly in their opposition to war and conscription, which they held was inimical to the concept of the brotherhood of man which they espoused.

Yet it is one of the major paradoxes of Doukhoborism that, despite their rejection of civil and religious authority, in reality they have proven submissive to more subtle forms of authority - revelation prophecy, tradition, and a succession of powerful leaders. Despite their liberal professions of individual freedom and human equality, they have historically adhered to and demanded fidelity to the demands of leaders, tradition, and group dictates; they cannot countenance nonconformity to the rigid behavioral injunctions which they have constructed. The basic contradiction of their proclamations of equality in the face of their overwhelming reliance upon a forceful leader has proven a major source of instability within the movement.

Ironically, it was a quarrel over the source of ultimate authority which evoked the first of a series of recurrent schisms which historically have rent the movement. For the Doukhobors, their oral tradition is more authoritative than the Bible, which is viewed allegorically, not literally. It was a dispute over the validity of this conception which produced the related sect termed the Molokans. Akin to the Doukhobors in the proclamations of the basic equality of all men, their rejection of external authorities, their hostility to war and military service, the Molokans diverged from them over the issue of the authority of the Bible and its relation to faith. Whereas the Doukhobors urged that the inner conscience should be the sole guide to faith, the Molokans proclaimed the Bible to be authoritative. The resulting schism weakened the Doukhobors, for in the decades which followed this break, the growth of the Molokans exceeded that of the Doukhobors, perhaps because of the Molokan Biblical literalness and their acceptance of the orthodox conception of the Trinity. The Molokan break with Orthodoxy, though decisive, was not so radical as the apparent total repudiation espoused by the Doukhobors. 13

By the end of the eighteenth century adherents of the tenets of the Doukhobors were scattered throughout all of Russia. The events of the nineteenth century were to prove especially significant in the develop ment of the sect. Externally, the attitude of the government of the Czar toward the Doukhobors alternated between one of intense persecution and one of indifferent toleration. Internally, the social structure which was to thereafter dominate the movement was formally initiated. The Doukhobor concept of the immanence of divinity in every man led some to proclaim themselves to be "more equal than others." The first of these, Pobirohin, proclaimed himself divine leader of the Doukhobors and established a theocratic despotism during the latter half of the eighteenth century. His leadership was ended abruptly by his exile to Siberia by civil officials during a period of governmental subjugation.

However, it was under the leadership of Saveli Kapustin, the rumored son of Pobirohon, that the hereditary theocratic principle upon which Doukhobor leadership has since rested was formally proclaimed and instituted. With the temporary relaxation of the previous harsh governmental policy, Kapustin led a large number of Doukhobors upon the first of several migrations to a frontier area in southern Russia known as the "Milky Waters." This event transformed what had been an atomistic and scattered group united only by ideology into a religious community; now community, rather than ideology, became the dominant cohesive force unifying them, and the prosletyzing which had been a salient feature of the movement previously ceased.

Most important for its later development, however, was the assumption of absolute rule by Kapustin, a decree issued in contradiction to the Doukhobor professions of equality. He proclaimed that, through transmigration, the soul of Jesus, which appeared once a generation, resided in him as it had in the early Popes, thus legitimizing the principle of hereditary leadership. The decree apparently did not generate any widespread or vocal opposition, for it was not inconsistent with the relation to authority with which most of the Doukhobor 
adherents, almost exclusively peasant, were familiar.

The void created by Kapustin's death dealt a severe blow to the (hich successors, in the persons of his son and grandson, inherited his position, but lacked the charismatic appeal which had enabled Kapustin to lay solid claim to leadership. Ineffective in their attempts to to larer council of elders which perpetuate his power, they capituated to a counce to remove the adopted a rule so inqui Doukhobors once more. During the years $1839-43$ over 4,000 adherent were transported still further into the frontier area of the Caucasu Mountains, where they ultimately prospered as an agricultural commu nity. nity. Leads who prondfather had proved inept. Kalmikoff died, however, without a legitimate heir to succeed him, but he left the leadership in the able person of his wife, Loukeria, who proved an enigmatic but dynamic influence upon the community.

Loukeria became attracted to the youthful Peter Verigin, who was umored, perhaps apocryphally, to have been the son of the late Kalmikoff At any rate, Loukeria commanded that Verigin divorce his wife, upon which he became her protege and was groomed to assume werengl inheritance of the leadership status provoked a violent controversy and produced a further schism in the group. The opposition to Verigin appealed to the civil authorities to uphold their rights to community property, which, if Verigin had won, would have reverted to his followers. The controversy culminated in Verigin's banishment by the authorities as a disturber of the peace in 1887 , but not before he had solidly established himself as the legitimate claimant of the right of succession.

Verigin's experience in exile greatly influenced his thinking, which he renitted in his frequent letters dispatched to his faithful disciples tras epistles from Siberia, filled with admonitions on proper behavior and the ideals which should define the group were erratic and ambiguous, but they provided a modicum of leadership for those several thousand who remained faithful to him. His cryptic pronouncements, deeply influenced by the radical political, religious, and social doctrines of his fellow exiles - among them Baptists, Stundists, and Tolstoyans - were avidly scrutinized for advice by the faithful.

Some of his admonitions proved so radical that a further rupture of the group resulted. He advised vegetarianism, the abolition of inequalities of wealth with a concomitant equitable distribution of all existing property, abstinence from intoxicants and tobacco, and sexual abstinence for an unspecified period. In addition, he urged that the
Doukhobors meet the crisis posed by governmental threats of military conscription by adherence to traditional pacifism. This he justified in eloquent manner with passages from Tolstoy and William Lloyd Garrison's 1843 "Declaration of Sentiments" plagiarized in its entirety. In response to Verigin's urgings and to dramatize their opposition to the government attempts at conscription, the "Mad" Doukhobors surreptitiously gathered all their existing weapons and ammunition and ignited them in a huge bonfire. This 1895 "burning of the guns" became an event of major significance for the later development of the sect.

Persecution of the "Mad" Doukhobors for their refusal to bear arms ensued unremittingly for the next decade, decimated the Doukhobor population, and scattered them throughout Georgia. The atrocities commited against them came to the attention of Count Leo Tolstoy. Unaware of the derivation of their tenets and the total reliance of the Doukhobors on Verigin, Tolstoy was greatly impressed with them, for they ostensibly personified the principles of simplicity and Christian anarchism which he espoused, and, what was more, their sentiments coincided with his own. Although the Doukhobors made no pretense to deny that Verigin was a leader among them, they refused to attribute any special significance to him. Their profession of faith, "We are al equal. We have no leader and none among us is greater than another," was memorized by the faithful who were simultaneously unable to arrive at any decision without authoritative advice from Verigin.

Tolstoy publicized their plight and championed them as objects of religious persecution at the hands of an oppressive government. $\mathrm{He}$ appealed on their behalf for financial aid to assist them and enlisted numerous reform leaders throughout the world in a campaign to secure their emigration from Russia. With the tacit but equivocal agreement of Verigin and the approval of the Russian government, several emigration proposals were presented. Aided by Tolstoy, who contributed the proceeds from his novel Resurrection, and a group of English Quakers over 7,000 Doukhobors emigrated from Russia during the period 1898-1900. Finding the dry and hilly climate of Cyprus unattractive to them, they found Canadian officials, greatly influenced by the humanitarian and reform sentiment which had been a prominent feature of the negotiations on their behalf, warmly receptive to their settlement of frontier territories and encouraged their settlement with liberal land allotments.

Difficulties arose almost immediately upon the arrival of the Doukhobors in Canada. The Canadian homestead laws; requirements of birth, death, and marriage records; and the small road tax levied upon them all generated conflict because of the Doukhobor insistence upon their right to refuse to observe the dictates of the Canadian officials. The individual most instrumental in negotiating their settlement with 
the Canadian officials, the English Quaker Alymer Maude, misunderstood and/or was misled by the Doukhobors and had been led to understand that the Doukhobors would consent to minor governmental regulation if their pacifism were respected. Further dissension arose within the group over the issue of communal ownership in the three Doukhobor communities. The situation remained unstable because the necessary authoritative leadership was lacking to initiate any concerted action.

In this vacuum of authority, the Doukhobors seized upon a number of sources, among Tolstoy's treatise urging the non-payment of taxes. Eagerly devouring anything from the pen of Verigin, they capitalized upon some esoteric letters written by Verigin but not meant for Doukhobor consumption. From these they derived justification for the first of the bizarre activities which were to define their existence in Canada to the present. The "Pilgrimage," a march into the wilderness of over 1,700 lightly clad Doukhobors in November of 1902 , was the most massive of what would become an institutionalized practice of marches.

Derived from the Biblical injunction to "render unto Caesar those things which are Caesar's," the Doukhobors, much to the surprise of the Canadian authorities, turned all their money over to them. They destroyed all things made of leather - boots, harness, coats, horse collara - and freed their cattle, which they proclaimed their "brothers." They removed all metal hooks from their clothing, discarded all needles and products of mines, in protest against exploitation of miners. All work was conceived to be sinful because Jesus hadn't worked. Then, armed with confidence ("yet your heavenly Father feedeth them ...."), they marched straight into the wilderness in search of a new land. They were temporarily provided with a sign of God's favor by mild weather and an assurance that God would provide a place with a warm climate. However, a blizzard ended this venture; it did not, on the other hand, erase the unrest or the precedence of this march from the memory of the Doukhobors.

Canadian officials, by this time somewhat cognizant of the divinity ascribed to Verigin and his position of authority among the Doukhobors, sought to minimize the mounting problems they encountered with the Doukhobors by joining with them in attempting to secure Verigin's release from his Siberian exile. Upon his return to the faithful, Verigin sought diplomatically to minimize the friction which had rent the group since their landing in Canada. He urged communal organization; he praised the zeal of the pilgrims but urged settlement; and he urged compliance with Canadian census registration. Except for a minority who, by a specious logic refused to comply, most Doukhobors followed his leadership and worked diligently to introduce a stable organization into the group. The small minority, terming themselves the
"Sons of Freedom," an appellation employed today by the most militant sect, in 1903 engineered a second pilgrimage, this time naked and in defiance of Verigin's orders. Verigin publicly denounced them and ordered them whipped in full view of the rest of the community; but the Sons of Freedom reasoned that they were merely "being tested" by him and their pilgrimages sporadically erupted several times over the next few years. The zealots then set fire to a mechanical binder which had been communally purchased, the first instance of incendiarism. It was this practice for which the Doukhobors would gain their notoriety over the next half century.

The patterns of bizarre behavior - nude parades and arson instituted in the first decade of the Doukhobors' existence in western Canada have persisted for a small minority to the present. Most of the descendants of those who migrated to Canada have followed the traditional pattern of adaptation to the status quo. While they have remained nominally Doukhobor, their integration into the larger society has been complete in many cases and only slightly less so in all but the fanatical Sons of Freedom, who today number about 7,000 of the total Doukhobor population in Canada of over 20,000. But during this period the conflict of the Canadian officials with the Sons of Freedom has grown more intense, and Canadian officials have grown increasingly pessimistic about reversing the trend. Also during this period groups of the more militant Doukhobors have attempted several times, with varying degrees of success, to migrate - initially to the neighboring provinces of Canada, later to Mexico, and more recently to South America. In 1958 there was even a drive instituted to return to Russia, a proposal squelched in its inception by the Russian refusal to consider their return.

The problems of Doukhobor leadership persist. Peter Verigin, an enigmatic but stabilizing influence upon the Doukhobors in Canada, was killed in a violent railroad explosion in 1924, which was apparently a product of Doukhobor incendiarism. The question of his successor raised again the confusion which had surrounded his succession. The decision to import his son, Peter Petrovich Verigin, from Russia to succeed him generated a furor and provoked a sizeable disaffection. Peter Petrovich proved less than dedicated to solving the problems demanded of a Doukhobor leader. The diplomacy which marked his father was conspicuously absent, and his dissipation and constant criminal offenses increased the already high level of frustration among his followers.

The depression provided the impetus for the moral and economic decline of the Doukhobors. During this period they became even further disorganized, and the dissension which erupted even within the relatively homogeneous Sons of Freedom was indicative of the atomization which characterized all of Canadian Doukhoborism. The 
death of Peter Petrovich in 1939 and the increased conflicts of the outside - especially the pressures derived from the war effort, which they found economically profitable - contributed still further to the demise of the Doukhobors as an organized and identifiable group. The instability occasioned by the leadership vacuum created by the death of Peter Petrovich remains acute for many of the more fundamentalistic of the Doukhobors. Several claimants to the position of leader have exploited gullible believers and extorted huge sums of money from the already impoverished Doukhobors, but at the present time the prospects of finding a legitimate, resourceful and dedicated leader which could institute some sort of stability into the militant Sons of Freedom sect appears negligible.

The conflict of the Sons of Freedom with the Canadian government continues unabated. Their opposition extends from political to educational institutions. They still refuse to bear arms, to vote, to pay taxes and to send their children to government schools. The depredations committed by the Sons of Freedom have increased in frequency. Although the majority of arson attempts have been committed against Doukhobor property, over $\$ 20,000,000$ in damages has been incurred in little over a century from this form of Doukhobor protest. 16

The most recent transformation of the Sons of Freedom leadership structure has involved an increasingly prominent role of women in perpetuating and dramatizing their fundamentalist position. The most recent burnings have been the product of female arsonists, and women effect a surprising coup de etat in supplanting men, who had traditionally ruled, in the council of the Sons of Freedom. This latter innovation is striking in that it reverses an earlier theological tenet. Despite professions of human equality, the early tenets of the Doukhobors included the denigration of women as "naturally stupid." The status of women had, prior to their recent assumption of power, been gradually enhanced, but not so dramatically as in this instance.

It would be impossible within the narrow confines of this paper to present an exhaustive and definitive analysis of the dynamics of Doukhoborism. However, an understanding of the movement is instructive, for the implications of several of its more prominent features are relevant to the derivation of any general theory of movements. Such analysis is perhaps impeded by the inclination to be distracted by the sensational behaviors manifested by the Sons of Freedom and to identify the movement with the problems of adjustment peculiar to this highly visible minority. The sources of the discontent of the Sons of Freedom have been adequately explored elsewhere, 17 and therefore reference to their peculiar problems will be minimal. The tendency to dwell upon the present adaptation of the Doukhobors not only slights the antecedent conditions from which their present adaptations germinated, but it also, and more significantly for the purposes of this analysis, obscures perception of the "natural history" of Doukhoborism in its totality.

The initial problem which arises concerns the nature of Doukhoborism as a movement. Heretofore we have considered, as have all source materials from which our information has been derived, Doukhoborism as a single movement, though one which has manifested an unusual historical tenacity and diversity of form. While acknowledging the continuity of the contemporary Doukhobor tenets and personnel with their eighteenth century origins, it is necessary to re-examine the validity of this assumption.

Doukhoborism, itself a product of a religious schism, has historically been plagued by internal conflicts which have periodically divided it into rival factions, each claiming legitimacy. At times, as in the controversy which produced the Molokans and in the split over Peter Verigin, the mutual repudiation has been violent and decisive. At other times, as the present uneasy alliance of Doukhobor sects in Canada reveals, disaffection has been occasioned by the intemperate actions of the more militant members and a more liberal attitude toward "Canadiazation." However, the spectacular nature of the Sons of Freedom has focused attention primarily upon that small fragment of those professing to Doukhobor doctrine. There appears to be no rational basis for considering the Sons of Freedom any more representative of Doukhoborism than their less militant and more acculturated brethren; the continuity of the latter from their eighteenth century antecedents is as clear as is that of the more militant Sons. A multiplicity of adaptations to the external community have therefore occurred under the broad panoply of Doukhoborism. The point has relevance for the selection of cultural activities which are to define a movement, for it appears that far too often groups so considered are chosen, as the Sons of Freedom would be, to represent a movement simply on the basis of the intensity of their deviation from and their protest against the status quo.

A further glance at the history of Doukhoborism reveals, furthermore, that, far from being a unitary phenomenon, it consists of a series of revitalization efforts, related but analytically distinct. The number of movements which can be identified are, admittedly, a function of the indices of the analyst. Nevertheless, the point remains that to consider Doukhoborism as a single, unitary movement is to obscure the numerous and varied alterations of the social order which have been proposed within Doukhoborism. The most obvious was the eighteenth century departure from the Orthodox religious tradition, which was a reaction against conditions existing in Russia during the period. Another attempt at revitalization, elicited by the state of anomie which pervaded Doukhobor society at the inception of their experience in 
Canada, was the initiation of the Pilgrimage.

The persistence of the bizarre behaviors which characterized this event suggests that this particular revitalization attempt has been institutionalized. This is supported by the rigidity with which the Sons resort to such behaviors to temporarily alleviate the frustrations they experience. But the adoption of this form of release has only furthered their alienation. The Sons' "mazeway" involves a misperception of the "real" world. Although their efforts do bring a temporary mitigation of stress, they do not actually remove, but further compound, the external conditions which they are attempting to realign. In the manner of a self-fulfilling prophecy they contribute to their own sense of estrangement.

The recent coup effected by the female Sons of Freedom suggests a third revitalization effort. The decisive manner in which the women seized power and the acquiescence of male members to their actions suggest that this is a most radical departure from previous practice. Enumeration of these recurrent revitalization efforts are useful in that they raise the question of adequate definition. Certainly more definite and concrete criteria to specify how radical and pervasive the cultural innovation must be would be more useful than Wallace's overly general definition of a movement as a "... deliberate, organized, conscious effort . . . to construct a more satisfying culture."18

A second theme, related to the recurrent fractionalization which has characterized the history of the Doukhobors, is essential to an understanding of the movement and pregnant with theoretical implications. This concerns the nature of the group's leadership structure, which comprises the major element of its more inclusive status system. The ambiguous nature of Doukhobor leadership has consistently proven a major source of strain, for controversy over the occupancy of the pivotal leadership status has inevitably precipitated schisms within the group. While the Doukhobors have consistently disclaimed any guidance but their individual consciences, in reality the traditional Russian peasant attitude toward authority has persisted. The authority of traditional religious and civil officials has merely been replaced by an intense reliance upon and subservience to the dictates of a strong and dynamic leader.

The simultaneous affirmation of these two greatly conflicting values was not consciously employed as a subterfuge, and they did coexist in a somewhat uneasy tension. The ambivalent denial of leadership and affinity for it have proven an inherent source of instability in Doukhoborism. The authority of ideology and tradition have continually conflicted; each has been selectively invoked as justification for opposing action programs. On the one hand, the vacuum created by the absence of a leader has led to a state of anomie, with heightened suggestibility, bizarre behavior, and a disintegration of the group without the initiation of any concerted action to ameliorate the situation. On the other hand, the ideal of individual freedom from coercion had traditionally been utilized not only in conflicts with civi authorities, but also in the several refusals to accept the claimant to succession.

Although most Doukhobors concur in the efficacy of the principle of n hereditary theocracy, there is no authoritative sanction in ideology for the working of an hereditary principle; doctrine works against it while tradition supports it. Therefore, although the hereditary principle is an ideal, the Doukhobors are never quite certain of its validity, and disputes inevitably ensue over the phenomenon of succession. Those who are disgruntled with the new leader are thereby provided with an explanation for their discontent - "He's not really the leader." This curious ambivalence, manifested in both hereditary and leadership principles, has contributed to the current instability of the Doukhobors, but it is inherent within the group itself, although often elicited by external conditions.

The amorphous social organization of the Doukhobors has consistently proven a source of disruption and stress, since the dependence upon the authority of a single leader proves it almost inherently unstable in the absence of one. Despite the Doukhobor espousal of democratic principles, the ruling councils which have assumed leadership in interim periods between leaders are invariably unstable and unable to achieve effective and binding leadership. Under them action becomes erratic and unpredictable and the Doukhobors become especially responsive to the bizarre and spontaneous. Given the psychological dependence upon the authoritarian guidance of a dynamic leader and the ambiguity of their ideology and tradition, the numerous marches, disrobings, and depredations appear not so much as irrational flights from reality but as logical consequences of these conditions. That others may derive divergent conclusions from the same premises does not invalidate their logic. But, most important, in the absence of structure, these conclusions do impel action; the zealots are removed from inactivity and a sense of impotence at being unable to effect their destiny.

The phenomenon of Doukhobor leadership has a direct bearing on the concept of charisma, which Wallace finds characteristic of revitalization movement organization.19 Max Weber, who developed the concept, contrasted the dynamism, spontaneity, and instability of charismatic power with the permanency and institutionalism of bureaucratic and patriarchal forms of power.20 The authority and control of the latter derive from the positions which these leaders occupy in the society, and it is by virtue of these offices that obedience and deference are claimed and/or accorded. The charismatic leader, on the other hand, derives power from the force of his own personality 
and message. It is not his occupancy of a powerful status position which creates for him a position of leadership but rather his dynamic role behavior.

The charismatic leader is often instrumental in generating a new movement. Yet ascription of the concept to innovators of new movements alone precludes use of the concept to explain the devotion which a leader such as Peter Verigin inspired but which many of his predecessors did not. Weber himself is not at all clear at this point. Although he defines charismatic, bureaucratic, and patriarchal power as ideal types, he seems also to have conceived of them as mutually exclusive. Yet it would seem to this writer that they need not necessarily be so. Charisma is a personal attribute which devolves on an individual irregardless of status position in a social structure; it is therefore relevant to the concept of individual role, or the manner in which an individual idiosyncratically enacts his various roles. The legitimacy of charisma has no institutional source but flows only from personal strength.

Bureaucratic and patriarchal power, on the other hand, are functions of the occupancy of status positions in the social structure and are inherent in the status irregardless of the individual occupant or the behavior he manifests. If this distinction between status and role functions of power is valid, it is entirely conceivable that an individual can combine bureaucratic and/or patriarchal leadership with the charismatic to generate an even more devoted following and wield an even more effective power. Indeed, it would appear that only by this type of distinction can the differential effectiveness of occupants of similar status positions be adequately accounted for.

When Doukhobor leadership is considered in these terms it is perhaps more comprehensible. The Doukhobor belief in the authority of patriarchal power vested in an hereditary figure has not inevitably produced stability. The movement has been almost utterly helpless without visionary and imaginative leadership from the individual who has occupied the top leadership position. It has thrived when, as under Peter Verigin, its leader was resourceful and imaginative; it has fallen into disarray, as under Peter Petrovich Verigin and under Vasily and Ilarion Kalmikof, when leadership has been uninspired and manipulative of its followers.

One of the major faults of Linton's paper on nativistic movements was the manner in which he confused a movement with the ideology which justified it. It was the equation of ideology and movement which enabled him to derive a scheme by which movements could be classified according to goals and means. However, it is apparent that a movement is a far more inclusive phenomenon than ideology, which is but one variable which contributes to and impinges upon a movement's totality and which may or may not be integral to its dynamics. The relation of ideology to the processural elements of a movement cannot be determined a priori; it is necessary to empirically evaluate the relative influence which ideology plays upon the specific movement under consideration.

A knowledge of the "career" of Doukhoborism is instructive at this juncture, for Doukhobor action would appear at first glance to be quite inconsistent with the ideology which they profess. The contradiction between Doukhobor profession and practice is obvious in terms of their receptivity to and reliance upon theocratic leadership in the face of their proclamations of equality and individualism. Ideology alone is also incompetent to explain several other features of the movement, notably the resort to violence as a means of protest. Ideology alone cannot explain the conflict which has been generated between Doukhobors and Canadian officials. Despite these inconsistencies many accounts have described the Doukhobors solely in doctrinal or theological terms and have remained oblivious to or ignorant of the behaviors which are in apparent conflict with their professions. $21 \mathrm{~A}$ more elaborate analysis of the variables which influence Doukobor behavior will not only serve to make their experience more comprehensible; it also contains implications for the evaluation of the role played by ideology in the success or failure of a movement.

The Doukhobor experience in Canada has been informed by several, at times inharmonious and conflicting, variables, but one of which was ideology. Occasionally, as in their opposition to the bearing of arms, ideology plays a dominant role and serves to unite even the most disparate elements of Doukhoborism, at which time the moderate Independent Doukhobors find themselves in a somewhat ambivalent alliance with the fanatical Sons of Freedom. However such instances of ideological primacy are not numerous. Formal Doukhobor ideology has historically been expressed in such general terms that it has been exposed to diverse interpretations and manipulation, but, like the United States Constitution, it has remained basically intact because great flexibility has been employed in its interpretation and use. It is paradoxical that, although the practices and behaviors rationalized by the Doukhobors are unintelligible in terms of their ideological professions, they can be understood only in terms of the influence of this ideology as perceived from within the historical-cultural contexts in which it operated. A brief elaboration of the manner in which other factors have related to ideology is essential.

The problem of adequately evaluating the role of ideology is, in the case of the Doukhobors, compounded by the fact that formal ideology, the explicit and formal goals of the movement, compose only a portion of their total belief system. The impact of Doukhobor oral tradition is a factor which has been neglected or minimized by most analysts, yet it 
appears to provide the basis for many of the apparent deviations from their formal ideology. Many of the actions of the Doukhobors had cultural antecedents or precedents in this tradition (e.g. migrations in search of a better land, opposition to government census taking, burnings as a means of protest), and the unwritten record of the development, the Doukhobor "myth," forms an integral aspect of their total culture. Although the Doukhobors rejected the efficacy of the Orthodox church and its rituals, their oral tradition antedates the formation of the sect. The historical experience of the sect in their relations with government and church do much to explain the antipathy and suspicion with which these institutions are viewed and the fact that Doukhobor professions of brotherhood are intra-societal rather than a universal extension of belief. This reliance upon the authority of tradition, at times apparently inconsistent with formal ideology, appears to have exerted a formative influence upon the sect.

It is essential to note that that which is apparently inconsistent and illogical may not be so adjudged by the Doukhobors, for it is their ability to submit their formal ideology to a tortuous exigesis which inevitably enables them to derive justification for their actions. Their reasoning, though objectively specious, is subjectively logical. Precedent for their constant attempt to decipher pronouncements for their hidden meanings was derived from the attempts of the Czar's government to proscribe the activities of the sect. The epistles which Peter Verigin dispatched to the faithful from his Siberian exile were constantly scrutinized for their veiled meanings, which action read significance into the slightest ambiguity.

Verigin, upon his return to the Community from his exile, advised his followers that they had not yet attained the level of goodness of Christ, and that, for the present, they should work to rebuild communal life. Several of the radicals perceived this as a "test" of their capacity to endure persecution for their faith. Secretly spreading their gospel of "freedom" they initiated the naked pilgrimage and were publicly whipped by Verigin for their defiance. But the justification for their reasoning was inherent within the belief system itself, for from their experience in interpreting Verigin's ambiguous letters, they could conceive of themselves as having to continually search for 'hidden meanings.' Rather than being inconsistent, their logic was most consistent and adapted to the peculiar conditions which they faced.

One of the features of the Doukhobor belief system which has received little publicity but which would appear to be an integral part of their total world view is their eschatological concept of the "third step," which, although mysterious and as yet concealed from them, will be revealed to them at some time. Their rejection of the validity of the established church and their pacifist stand, personified in the "burning of the guns," are the first and second of this trio, respectively. Precisely how this concept evolved is obscure, but its experiential significance is clear. The "third step," coupled with a heightened suggestibility derived from their search for "hidden meanings" leaves a feeling of uneasiness among many who find the ambiguity unsettling. Speculation over what specific action the "third step" shall entail is ubiquitous among the more fundamentalistic of the Doukhobors. Often belief in its imminence has been employed to sanction innovations, such as communal living. But its total effect has been to provide a further source of irritability and instability which contributes to the Doukhobor sense of alienation. 22

The Doukhobor religious revolution was a decisive and radical one, but the form, both ideological and institutional, which the movement adopted was greatly influenced by the pre-existing cultural system. Major elements of Russian peasant culture remained intact and were perpetuated; many of these persist as integral aspects of Doukhobor culture. Indeed, as in the case of the Molokans, 23 the rural Russian peasant tradition remains a dominant strain in Doukhobor culture. This is evident in their overt culture, perhaps personified in the sobranie, the traditional meeting or gathering, in which bread, water, and salt are partaken and traditional songs are sung. The lavish eating, the diet, the games, the steam baths are all elements of the traditional patterns, exclusive of ideology, which serve to reinforce their in-group cohesive ness and impede acculturation. It would appear that many of the conflicts which have developed since the Doukhobor's migration to Canada are attributable to those problems of adjustment which have confronted innumerable minority groups who have sought to migrate into a new cultural setting. Although the Sons of Freedom justify their campaign against the government in terms of its invasion of their "freedoms," it is apparent that their real fear is acculturation and alteration of their present cultural system, not its ideological aspects alone.

The problems of immigrant adjustment encountered by the Doukhobors relate to a fourth factor which has influenced Doukhobor experience - the external situation which the Doukhobors confront. Much of Doukhobor behavior has been shaped by external forces and the Doukhobor reaction to them in both their Russian and Canadian environments. The Doukhobor opposition to government was elicited by the tyranny of autocracy and its enforcement of the observance of state religious practices. The Doukhobor attitudes toward government, a product of their Russian experience, were perpetuated into a new situation in Canada in which they have become anachronistic. However, few of the Doukhobors perceived that democratic government differed significantly from the form which had elicited their initial hostility.

The migration of the Doukhobors to Canada did much to generate their later revitalization attempts, for it introduced an already unstable 
structure into an unfamiliar environment. Far from alleviating the tension which their migration had sought to relieve, it was merely heightened by this maneuver. Although their formal ideology proved no impediment to their adjustment to Canadian society, their alien culture, nationality, language, and their unfamiliarity with a more complex system of economics and technology did. It was specific grievances and frustrations derived from their relation to this environment which in many instances has elicited their notorious means of protest.

\section{FOOTNOTES}

1 Ralph Linton, "Nativistic Movements." American Anthropologist, $45,(1943), 230-40$.

2 Anthony F. C. Wallace, "Revitalization Movements," American Anthropologist, 58, (1956), 264-81.

3 C. Wendell King, Social Movements in the United States, (New York, Random House, 1956).

4 This psychological sense of estrangement has been variously designated as "strain" (Talcott Parsons, "The Processes of Change of Social Systems in The Social System, [Glencoe, The Free Press, 1951] ); "stress" (Wallace, "Revitalization Movements"); "dissatisfaction with the status quo" (Linton, "Nativistic Movements"); "oppression" (Peter Worsley, The Trumpet Shall Sound, [London, MacGibbon and Kee, 1957]); "objective circimstances productive of subjective feelings of threat" (Munro S. Edmunson, "Nativism, Syncretism, and Anthropological Science" in Nativism and Syncretism, [Publication 19, Middle American Research Institute, Tulane University, New Orleans, 1960] 181-203); "deprivation" (Bernard Barber, "Acculturation and Messianic Movements," American Sociological Review, 6, [1941] , 663-69); "individual discontent" (King, Social Movements). Even if the predictions are valid, it is impossible to predict the form a movement will take. It may be a satisfactory innovation or one, as in the case of the Doukhobors, which may merely intensify the stresses.

5 Linton, "Nativistic Movements."

6 See e.g. Edmunson, "Nativism, Syncretism, and Anthropological Science"; Worsley, The Trumpet Shall Sound; Marion W. Smith, "Toward a Classification of Cult Movements" Man, 59, (Jan. 1959) 8-12; and what is perhaps the apotheosis of this emphasis upon classification - A. J. F. Kobben, "Propehtic Movements as an Expression of Social Protest." Internation Archives of Ethnography, 49 (1960), 117-74.
7 Liston Pope, Millhands and Preachers, (New Haven, Yale, 1942).

8 Wallace, "Revitalization Movements."

9 Parsons, "The Processes of Change."

10 King, Social Movements.

11 Research on the origins of the Doukhobors is hampered by the lack of written records - attributable both to the low level of literacy of the Doukhobors and the refusal of the Soviet government to permit access to those records which do exist. It is further impeded by the distrust of outsiders manifested by most Doukhobors, which renders them almost inaccessible, even at present.

In the descriptive aspects of this paper I have leaned quite heavily on several works. J. F. C. Wright's Slava Bohu: The Story of the Doukhobors (New York 1940) is a popular and sympathetic but extremely informative chronology of the Doukhobor experience. It most closely approximates a definitive work on the totality of Doukhoborism. It is marred by the lack of a bibliography and the absence of footnotes, but it does justice to the complexity of the problem of Doukhobor adjustment.

For Doukhobor origins I relied primarily upon Paul Miliukov, Outlines of Russian Culture, (Philadelphia, Pennsylvania, 1942) I, which provides a view in depth of the religious turbulence in Russian society. Miliukov maintains that the growth of Sectarianism cannot be attributed to foreign influences, but that its origins must be sought within Russian religious life itself. Deeply immersed in the theory of developmental stages (The work was originally published in 1904.) he feels that the emergence of the Doukhobors and allied sects merely reflected what had previously occurred in the German reformation when, in reaction against the established church, a period of Bibliocentric Christianity was instituted, only to be followed by a purer, more pristine stage, "Spiritual Christianity" which he finds personified in the Doukhobors.

Frederick C. Conybeare's Russian Dissenters (Cambridge, Harvard, 1921) is deeply indebted to Miliukov, but seeks to emphasize the non-religious elements in Russian religious life and focuses more intensely upon the Schism than does Miliukov.

For analysis of the contemporary situation, Harry B. Hawthorn, ed., The Doukhobors of British Columbia is required reading Though quite uneven, since it was a joint project of the Doukhobor Research Committee appointed as a Royal Commission to investigate and draw up recommendations to the Federal Government on means of ameliorating the Doukhobor problem. Admittedly problem oriented, it does not dwell upon the historical evolution of the sect, but it is exhaustive in its treatment of the psychological and sociological problems confronting the contemporary Doukhobors. 
12 Conybeare, 42. The disputes over ritual involved such issues as the number of times (two or three) the Alleluia was to be recited before the Gloria in the Mass, whether the dating of documents was to be from the beginning of Creation or from the birth of Christ. A further dispute arose over the correct number of fingers (two or three) which were to be employed in making the sign of the cross and in several other aspects of liturgical formulae.

13 Miliukov, 102. On the Molokans and the problems of adjustment which they encountered in the United States, see Pauline V. Young, The Pilgrims of Russian Town: The Struggle of a Primitive Religious Society to Maintain Itself in an Urban Environment. (Chicago, Chice the study of the Molokans, she was primarily interested in the into American society and the problems it fostered.

14 Alymer Maude, A Peculiar People: The Doukhobors (New York, Funk \& Wagnalls, 1904). Maude relates his entire experience in arranging for the Doukhobor migration to Canada. He is somewhat disillusioned with the Doukhobors for what he claimed not unjustly, was duplicity on their part. unjustly, was duplicity on their part. He also seeks to trace the origins

15 The latest events in the history of the Doukhobors in Canada were gleaned from a number of reports in the New York Times and Time Magazine. Such reports were admittedly inadequate because they usually emanated only as a result of a nude march or a notable depredation by the Sons of Freedom. The record of the notable depredation by th "Doukhobors is brought practically up to date in Paul H. Avrich ian Review, 21, (July 1962), 264-76.

16 Ibid.

17 Hawthorn, The Doukhobors.

18 Wallace, "Revitalization Movements," 265

19 Ibid., $273 \cdot 74$.

20 Hans Gerth and C. Wright Mills, ed., From Max Weber: Essays in Sociology, (New York, Oxford, Galaxy Edition, 1958) 246-250.

21 See e.g. A. Palmieri, "The Russian Doukhobors and Their Religious Teachings," Harvard Theological Review, 8 (1915), 62-81.
22 The only evidence of this phenomenon which I could find was in an unimaginative dissertation by one of the members of the Doukhobor Research Committee. Gordon K. Hirabayashi, "The Russian Doukhobors of British Columbia: A Study of Social Adjustment and Conflict" (Unpublished doctoral dissertation, University of Washington, 1951)

23 See Young, The Pilgrims of Russian Town. 